\title{
Nápoje na dvorech králů a knížat z dynastie Jagellonců konce 15 . a počátku 16. století
}

\section{PETR KOZÁK}

Kozák, Petr: Beverages at the Courts of the Kings and Princes of the Jagiellonian Dynasty in the Late $15^{\text {th }}$ and early $16^{\text {th }}$ Century

This study presents an analytical probe into the field of beverage culture as it was cultivated in the late $15^{\text {th }}$ and early $16^{\text {th }}$ century at the courts of the descendants of the Polish-Lithuanian ruler Casimir IV († 1492) of the Jagiellonian dynasty: the Czech and Hungarian king Vladislaus ( $\uparrow 1516)$, his son, the Czech and Hungarian king Louis ( $† 1526)$, and then his brothers, the Polish king John Albert ( $\dagger 1501)$, the grand duke of Lithuania and later also the Polish king Alexander ( $\uparrow 1506)$ and the future Polish-Lithuanian ruler (the then Duke of Opava and Gtogów and the governor of Silesia and Lusatia) Sigismund († 1548). The starting point of the research was a comprehensive analysis of rare, preserved account books kept at the courts of these monarchs. This study describes the various types of beverages consumed (especially wine and beer) both in the social and geographic context. In addition, it also includes the sphere of consumers' taste preferences.

Key Words The Jagiellonians; Accounts; Culture; Beverages; Middle Ages

doi.org/10.15452/Historica.2021.12.0007

Contact Slezská univerzitavopavě; petr.kozak@fpf.slu.cz

Konzumace potravy nebyla v minulosti (a není ani dnes) pouhým uspokojováním biologických potřeb člověka. V rámci lidských společenství plní jídlo a zejména sociokulturní kontext konzumace jídla roli jednoho z výrazných nonverbálních nástrojů sociální a mocenské komunikace. Vedle samotného fenoménu pospolité konzumace, která pomáhala vytyčovat (vizuálně zpřítomňovat) hranice konkurujících si, či kooperujících společenských formací (vrstev, skupin), lze poukázat na samotnou dostupnost určitých více či méně exkluzivních pokrmů a nápojů coby jeden ze základních distinktivních znaků, jež komunikovaly navenek sociální exkluzivitu, resp. marginalitu daného společenství. Zjednodušeně řečeno, ne každé jídlo a pití bylo pro každého, co člověk jedl a pil, tím také (v očích současníků) do značné míry byl. Historie jídla proto dnes není ani zdaleka výlučným hájemstvím odborníků na hmotnou kulturu a hospodářské dějiny. Naopak se jedná o tematické pole navýsost interdisciplinární, nebot široce pojímaný fenomén kulinární kultury interesuje zástupce řady oborů od historie, etnologie a antropologie až po literární vědu a sociologii. Původně anglosaský metodický koncept food history, zacílený na jídlo jako specifické médium sociální komunikace, ${ }^{1}$ je dnes široce recipován rovněž

\footnotetext{
Studie byla vypracována v rámci řešení projektu id. č. DG18P02OVV067, financovaného z Programu na podporu aplikovaného výzkumu a experimentálního vývoje NAKI II.

1 Srov. CEISEL, Christina: Food Studies, In: OxfordResearch Encyclopedia of Communication. Oxford 2017. Online, cit. 1.9.2021 dostupné na https://doi.org/10.1093/acrefore/9780190228613.013.580, resp. https://oxfordre .com/communication/view/10.1093/acrefore/9780190228613.001.0001/acrefore-9780190228613-e-580.
} 
vědeckou obcí ve střední a východní Evropě. ${ }^{2}$ A to včetně české (nejen) historické vědy, kde sehrávají koordinační roli univerzitní pracoviště pardubické a opavské. ${ }^{3}$

Předkládaná studie má být svého druhu analytickou sondou do světa nápojů, které byly kolem roku 1500 podávány na dvorech potomků polsko-litevského vládce Kazimíra IV. († 1492) z rodu Jagellonců. Zacílení na příslušníky jagellonské dynastie v jedné, resp. dvou generacích má svůj smysl hned z několika důvodů. Předně Jagellonci v daném čase ovládali obrovské prostory střední a středovýchodní Evropy, pod jejich žezlem se tak ocitly země s rozdílnými historickými (v tom též kulinárními) tradicemi i prírodními podmínkami, jež přirozeně výrazně promlouvaly do podoby lokálního trhu s potravinami. ${ }^{4}$ Nabízí se tak otázka, zda a případně jakým způsobem tato predispozice ovlivnila konzumaci nápojů u panovníkova stolu a v jeho nejbližším okolí. Současně má moderní historik v případě Jagellonců vládnoucích ve výše vymezeném čase k dispozici mimořádně zajímavý a informačně atraktivní soubor pramenů, jímž jsou dvorské účty dochované více či méně torzovitě de facto pro každého ze samostatně vládnoucích jagellonských monarchů. V případě českého a uherského krále Vladislava $(† 1516)$ jsou k dispozici provenienčně „polské“ účty z roku 1471, kdy se mladý Jagellonec vydal z Krakova do Čech, dále tzv. registra verková, tedy účty vedené při mincovně v Kutné Hoře, do nichž byly zaznamenány i některé z výdajů panovníkova dvora, a pak evidence prŕjmmů a výdajů Vladislavova budínského dvora z let 1494-1495, kterou nechal sestavit tehdejší uherský královský pokladník, pětikostelský biskup Zikmund Ernuszt. ${ }^{5}$ Pro období vlády Vladi-

\footnotetext{
2 Dlouhodobě progresivní je v tomto ohledu polská věda. Upozornit lze např. na ediční řadu Monumenta Poloniae Culinaria vydávanou Muzeem Pałacu Króla Jana III w Wilanowie nebo na Centrum Dziedzictwa Kulinarnego činné při Ústavu historických věd Univerzity Mikuláše Koperníka v Toruni. Spiritus movens obou podniků je Jarosław Dumanowski. Z poslední doby lze odkázat např. na kolektivní dílo KAMLER, Anna - PIETRZKIEWICZ, Dorota - SEROKA, Katarzyna (eds): Polska i świat przez kuchnię : Studia o dziedzictwie kulinarnym. Warszawa 2018.
}

3 Na Univerzitě Pardubice se kolektiv pod vedením Mileny Lenderové dlouhodobě zaměřuje zejména na mnohovrstevnatou analýzu kuchařských knih. Viz JEDLIČKOVÁ, Blanka - LENDEROVÁ, Milena - KOUBA, Miroslav - ̌̌ÍHA, Ivo (eds.): Krajiny prostřených i prázdných stolů I. : Evropská gastronomie v proměnách staletí. Pardubice 2016; TÍŽ (eds.): Krajiny prostřených i prázdných stolů II. : Evropská gastronomie v interdisciplinárním prístupu. Pardubice 2017; LENDEROVÁ, Milena - KOUBA, Miroslav - KOZÁR, Aleš - ŘíHA, Ivo: „Spanilost Vaše cizozemcům se líbí... “: České kuchařské knihyv 19. století. Červený Kostelec 2017. Na půdě Slezské univerzity v Opavě se výzkumný tým vedený Irenou Korbelářovou věnuje kontextuálnímu výzkumu kulinárního dědictví českých zemí. Viz KORBELÁŘOVÁ, Irena a kol.: Kulinární kultura Slezska a střední Evropy: Východiska, metody, interdisciplinarita. Opava 2015; KORBELÁŘOVÁ, Irena - ZEZULA, Michal (eds): S knížaty u stolu : Kuchyně a kultura stolování na středověkých vévodských dvorech v Opavě a Ratiboři. Ostrava - Racibórz 2018; KORBELÁŘOVÁ, Irena - DLUHOŠOVÁ, Radmila - SOBOTKOVÁ, Jitka: Pamèt chuti : Receptáre a kuchařské knihy jako specifické prameny pro poznání kulinární kultury a kulinárního dědictví českých zemí. Opava 2020; JANÁK, Dušan a kol.: Jídlo není jenom „něco k jídlu“ : Tradiční stravování a pokrmy jako součást regionální a národní identity ve vědomí a paměti současné společnosti. Opava 2020.

4 Potenciál tématu spíše jen naznačili BOŁDYREW, Aleksander - BOŁDYREW, Aneta: Royal Bills as the Source of the History of Taste and Food in Poland of the Last Jagiellons: Basic Sources and Research Possibilities. Piotrkowskie Zeszyty Historyczne 15, 2014, s. 11-27.

5 Verková registra (s četnými pramennými citacemi) vytěžil TRNKA, Pavel: Výdaje dvora Vladislava Jagellonského v letech 1471-1490. In: Dvory a rezidence ve středověku III. : Všední a sváteční život na středověkých dvorech. Mediaevalia Historica Bohemica 12, 2009. Supplementum 3, s. 271-292. Další ze zmiňovaných účtů publikovali PERZANOWSKI, Zbigniew - STRZELECKA, Anna: Część I: Rachunki wyprawy Władysława Jagiellończyka do Czech w latach 1471-1472. In: GAWĘDA, Stanisław - PERZANOWSKI, Zbigniew - STRZELECKA, Anna: Rachunki królewskie z lat 1471-1472 i 1476-1478. Wrocław - Kraków 1960, s. 1-101; KOZÁK, Petr: Účty budínského dvora krále Vladislava II. Jagellonského (1494-1495). Praha 2019; NEUMANN, Tibor: Registrum proventuum regni Hungariae : A Magyar Királyság kincstartójának számadáskönyve (1494-1495). Budapest 2019. Srov. též studii KOZÁK, Petr: Income and expenditures of the Hungarian Royal Chamber during the first ruling years of 
slavova syna, českého a uherského krále Ludvíka († 1526), se dochovaly zlomky účetní materie z kritických let $1525-1526 .{ }^{6} \mathrm{~V}$ případě Polského království a Litevského velkoknížectví se sice evidence prŕjmů a výdajů panovníků a jejich dvorů dochovala do dnešních dnů v nepoměrně ucelenějších řadách, přesto se jedná o torzo původně obsáhlejší agendy. Řada svazků byla navíc z podstatné části či zcela věnována soupisům dvořanů (a jejich koní) s evidencí služného, výdaje na každodenní provoz dvora, v tom též zaopatření dvora jídlem a nápoji, v nich absentují. ${ }^{7} \mathrm{~K}$ dispozici je pět svazků účetní evidence z období vlády polského krále Jana Albrechta $(\dagger 1501)^{8}$ a celkem sedm foliantů spojených s provozem litevského a posléze polského dvora jeho bratra Alexandra († 1506). ${ }^{9}$ Představený soubor pramenů účetní povahy pak uzavírá trojice register sestavených u dvora prince Zikmunda († 1548), pozdějšího polsko-litevského vládce Zikmunda I. Starého, který se před převzetím trůnů v Krakově a Vilně pohyboval mezi dvory panujících sourozenců, stal se knížetem v Opavě a dolnoslezském Hlohově a v letech 1504-1506/1507 zastával úřad místodržícího českého krále ve Slezsku a v obou Lužicích. ${ }^{10}$

\section{Víno}

Obecně lze říci, že víno bylo vznešenějším nápojem než pivo. Jeho konzumace proto tradičně doplňovala paletu distinktivních znaků, s jejichž pomocí dvorské prostředí komunikovalo vůči okolí svoji sociální a kulturní exkluzivitu. Zejména pokud se jednalo o vyloženě luxusní, zpravidla importované druhy vín, které nebyly dostupné každému. Takto formulovaná teze samozřejmě neplatila absolutně. Vždy záleželo též na chutových preferencích konkrétních lidí, kvalitě (producentovi), druhu a způsobu využití - vždyt' víno se nejen pilo, používalo se ho hojně i v kuchyni jako přísady do řady pokrmů (v účtech byla vína takového určení označována obvykle za pomoci obratů ad coquinam či ad cibaria apod.). Z vína i piva se také běžně vyráběl ocet. Opomenout nelze ani křestanský liturgický provoz, jenž byl bez vína stěží představitelný. Záznamy o vínu darovaném panovníky pro potřeby kostelů a klášterů jdou napříč všemi analyzovanými

King Vladislaus Jagiellon: analysis of an accounting register from the years 1494-1495. In: SLAVíČKOVÁ, Pavla (ed.): A History of the Credit Market in Central Europe: The Middle Ages and Early Modern Period. London - New York 2020, s. 42-51.

$6 \quad$ FRAKNÓI, Vilmos: II. Lajos király számadási könyve. 1525. január 12-július 16. In: Magyar történelmi tár XXII. Budapest 1877, s. 45-236; ENGEL, Johann Christian: Fragmentum libri rationarii super erogationibus aulae Regis Hungariae Ludovici II. de anno 1526. In: TÝŽ: Monumenta Ungrica. Viennae 1809, s. 185-236.

7 Široce rozvrženou analýzu obsahové stránky a badatelského potenciálu polských královských účtů nabídla BORKOWSKA, Urszula: Rachunki królewskie jako źródło poznania praktyk religijnych Jagiellonów. In: BORKOWSKA, Urszula - KNAPIŃSKI, Riszard - PIŁAT, Zbigniew - WIŚNIOWSKI, Eugeniusz (eds.): Peregrinatio ad veritatem : Studia ofiarowane profesor Aleksandrze Witkowskiej OSU z okazji 40-lecia pracy naukowej. Lublin 2004, s. 47-63.

8 Archiwum Główne Akt Dawnych (dále AGAD), Archiwum Skarbu Koronnego z lat 1388-1826 (Nr. Zespołu: 7), Oddział 1 - Rachunki Królewskie, 1388-1781 (dále ASK-RK), sign. 20, 22, 24, 26, 28.

9 AGAD, ASK-RK, sign. 30-32, 34; ANTANAVIČIUS, Darius - PETRAUSKAS, Rimvydas: Lietuvos didžiojo kunigaikščio Aleksandro Jogailaičio dvaro sąskaitų knygos (1494-1504). Vilnius 2007.

10 KOZÁK, Petr: Účty dvora prince Zikmunda Jagellonského, vévody hlohovského a opavského, nejvyššího hejtmana Slezska a Lužic, z let (1493) 1500-1507: Kritická edice pramene / Rationes curiae Sigismundi Iagellonici, ducis Glogoviensis et Opaviensis, Silesiae et Lusatiarum summi capitanei, de annis (1493) 1500-1507: Editio critica. Praha 2014; KOZÁK, Petr - RÁBAI, Krisztina: Mezi periferií a centrem jagellonského světa: Registrum dvořanů knížete a krále Zikmunda I. Jagellonského z let 1493-1510 / Between the Periphery and the Centre of the Jagiellonian World: The Register of Courtiers of Prince and King Sigismund I Jagiellon from 1493-1510. Opava 2015. 
svazky účetní evidence. Dostupnost i kvalita vína bývala podmíněna rovněž geograficky. Jagellonci ovládali podstatnou část střední a středovýchodní Evropy, pod jejich žezlem se tak nalézaly jak tradiční vyhlášené vinařské regiony v Uhrách či v českých zemích, tak také severněji položené oblasti Polska a Litvy (tedy včetně dnešního Běloruska a Ukrajiny), kde nepříznivé klimatické podmínky vinohradnictví nepřály.

Velmi dobrý zvuk mívala již ve středověku vína uherská. Vína původem z českých zemí, tedy z Čech a z Moravy, nebot' Slezsko a Lužice mezi standardní vinařské oblasti počítat nelze, zůstávala v porovnání s uherskými víny, která si např. jagerský a ferrarský biskup a blízký př́ibuzný uherské královny Beatrix Aragonské Hypolit d'Este nechával na počátku 16. století dovážet ze svých uherských držav i do rodné Itálie, ${ }^{11}$ fenoménem spíše regionálním. Král Vladislav preferoval dle dochovaného účetnictví víno před jinými alkoholickými nápoji již v době, kdy panoval toliko v Čechách a rezidoval v Praze (tedy před rokem 1490). Víno pořizovali pro potřebu jeho dvora měštanští kupci pravidelně. O původu vína povětšinou mnoho nevíme, nebot' se, slovy účetní evidence, platilo jednoduše za víno. Nevíme proto obvykle, jednalo-li se o domácí (českou) produkci, nebo o importy. Ovšem roku 1471 bylo na přání krále Vladislava přinejmenším podvakráte nakupováno výslovně litoměřické víno (vinum de Luthomirzice). ${ }^{12}$ Jinak účetní písaři zachycovali původ vína de facto výlučně v těch prrípadech, kdy šlo o skutečně luxusní, a tedy i drahé nápoje - pro potřeby krále Vladislava byly dováženy bečky vyhlášeného sremského vína vyráběného v kraji mezi Sávou a Dunajem poblíž horké uhersko-osmanské hranice. Bečka, kterou nechal kutnohorský měštan Šípecký zaslat králi do severočeského Mostu, ${ }^{13}$ tak vyšla na více než 48 kop grošů a jeho cena tím několikanásobně převýšila průměr výdajů za „běžné“ víno. Opakovaně bylo pro potřeby pražského dvora krále Vladislava nakupováno i řecké víno, zpravidla společně s jinými exotickými pochutinami, jako byly mandle, fíky, cukr nebo rýže. ${ }^{14}$

Preference vína ze strany krále Vadislava našla odraz i ve skutečnosti, že dochované účetnictví jeho dvora z let 1494-1495, a tedy v době, kdy již rezidoval v uherském Budíně, neobsahuje ani jeden jediný záznam o akvizici piva. Víno ovšem panovník a jeho okolí konzumovali pravidelně v nemalém množství. ${ }^{15}$ Při př́ležitosti Vladislavovy české korunovace v roce 1471 byl z př́kazu Petra Kdulince z Ostroměře zakoupen za 55 zlatých celý drajlink vína, tedy přibližně 1240 litrů. ${ }^{16}$ A kupříkladu v dubnu 1523 vyčíslil uherský královský pokladník Alexius Thurzó roční náklady spojené s nákupem „běžného“ vína pro osobní spotřebu krále Ludvíka (ad emptionem vinorum pro ore regie maiestatis) na celých 832 zlatých. ${ }^{17}$ Dobrým uherským vínem nechával král Vladislav pravidelně zásobovat rovněž nejrůznější vznešené návštěvníky a diplomatická poselstva - uctil tak např. repre-

\footnotetext{
11 E. KOVÁCS, Péter: Estei Hippolit püspök Egri számadáskönyvei 1500-1508. Eger 1992, s. 173.

12 PERZANOWSKI, Z. - STRZELECKA, A.: Rachunki wyprawy, s. 77, 87.

13 TRNKA, P.: Výdaje dvora, s. 281-282.

14 Tamtéž, s. 283.

15 KOZÁK, P.: Účty budínského dvora, s. 108, 114, 134-135, 137, 142-143, 152, 164-165, 203, 211, 248, 272, $279,281,284$.
}

16 PERZANOWSKI, Z. - STRZELECKA, A.: Rachunki wyprawy, s. 72. Objem drajlinku (duté míry s obsahem tř́i čtvrtin fudru) v litrech viz Elektronický slovník staré češtiny. Praha, oddělení vývoje jazyka Ústavu pro jazyk český AV ČR, v. v. i., 2006-, přístupné online: http://vokabular.ujc.cas.cz (verze dat 1.1. 17, citován stav ze dne 30.4. 2021).

17 C. TÓTH, Norbert: Politikatörténeti források Bátori István első helytartóságához (1522-1523). Budapest 2010, s. 257. 
zentanty osmanského sultána Bajezida II. a římského krále Maxmiliána I., papežského legáta Orsa Orsiniho, vyslance moldavského vévody Štěpána III. či členy poselstva valašského knížete Vlada V., stejně jako diplomaty, kteří do uherské metropole přicestovali z pověření jeho bratra, litevského velkoknížete Alexandra Jagellonského. ${ }^{18}$

Záznamy o víně $\mathrm{v}$ dochovaných účetních pramenech spojených $\mathrm{s}$ provozem dvorů panovníků z dynastie Jagellonců přelomu 15. a 16. století jsou převahou velmi nekonkrétní, pokud jde o informace stran druhu, kvality a původu evidovaného vína. Dokonce se zpravidla ani nedozvídáme, zda se jednalo o víno červené, nebo bílé. Jak již bylo řečeno, platilo se jednoduše za víno (pro vino apod.). Lakonické záznamy o výdajích za víno přitom prostupují dochovanými knihami účtů dvorů všech Jagellonců doby kolem roku 1500, tedy Vladislava, Zikmunda, Alexandra i Jana Albrechta, a podobně je tomu s materií pro léta 1525-1526, která je k dispozici v případě dvora syna a dědice Vladislava Jagellonského, uherského a českého krále Ludvíka. Výjimku potvrzující pravidlo představují především opakované zmínky o akvizicích sremského vína, které se těšilo setrvalé oblibě nejen u dvora králů Vladislava a Ludvíka, ${ }^{19}$ ale také u mladšího bratra krále Vladislava, prince (a pozdějšího polsko-litevského vládce) Zikmunda. Ten neváhal roku 1504 při pobytu ve slezské Vratislavi věnovat bečku tohoto lahodného moku i svému hostiteli, měštanovi Janu Bockwitzovi. ${ }^{20}$ Dva sudy sremského vína poslala roku 1525 králi Ludvíkovi do města Hatvan i jeho manželka, královna Marie Habsburská. ${ }^{21}$

Ostatně o Zikmundovi z dochovaných účtů víme, že si ještě za svého pobytu v Uhrách nechal dovážet „vídeňské“, tedy rakouské víno (vinum Vienense). ${ }^{22}$ A po přesídlení do Slezska byly pro jeho knížecí tabuli nakupovány sudy uherského vína (vinum Hungaricale). ${ }^{23}$ Jisté rozdíly $\mathrm{v}$ druhu a kvalitě vín lze dedukovat $\mathrm{z}$ účtovaných sum, ovšem zde narážíme na problém obrovského geografického rozsahu jagellonských držav, kdy cena vína $\mathrm{v}$ oblasti jeho produkce (především tedy v Uhrách) byla podstatně nižší než cena vína $\mathrm{v}$ oblastech, kam muselo být komplikovaným způsobem dováženo, jakkoli mohla být (a nejspíše i byla) jeho kvalita ve skutečnosti spíše nižší. Rozdíly v kvalitě „běžného“ vína lze ovšem oprávněně předpokládat, vždyt např. roku 1494 dodávali pro potřeby krále Vladislava měštané z Pešti vinum za cenu 16 zlatých za bečku i 24 zlatých za bečku. ${ }^{24}$ Víno vyhrazené služebnictvu jistě nesneslo srovnání s nápojem, který šenk naléval do pohárů určených pro panovníka, jeho hosty a dvořany. V některých případech se účetní písaři uchýlili rovněž k charakteristice vína za pomoci jeho geografického původu - král Ludvík si tak roku 1525 dopřál víno vypěstované v Baranské župě na pomezí dnešního Mad'arska a Chorvatska či ve Felhévízu na budínské straně Dunaje. ${ }^{25}$ Místo původu vína přitom bývalo považováno za důležité. Fragmenty účetních knih jednoho z uherských magnátů, pana Ladislava Kanizsaiho, z let 1518-1523 důsledně dělí vinařskou produkci na jeho západouherských statcích podle jednotlivých lokalit (Deutschkreutz, Cenk, Kövesd, Iván, Csepreg, Sótony, Ölbő, Kanizsa, Újudvar, Gelse a Ság), navíc zmiňují různě kořeněná vína,

\footnotetext{
KOZÁK, P.: Účty budínského dvora, s. 114, 134, 137, 165, 211, 284.

9 Tamtéž, s. 164, 272; FRAKNÓI, V.: II. Lajos király számadási könyve, s. 60, 231.

20 KOZÁK, P.: Účty dvora, s. 337, 342.

21 FRAKNÓI, V.: II. Lajos király számadási könyve, s. 231.

22 KOZÁK, P.: Účty dvora, s. 82.

23 Tamtéž, s. 342.

24 KOZÁK, P.: Účty budínského dvora, s. 211.

25 FRAKNÓI, V.: II. Lajos király számadási könyve, s. 60, 118.
} 
jakými bylo víno šalvějové (vinum salviaticum) a pelyňkové (vinum absintheatum, resp. absinteaticum), a vína charakterizovaná svým stárím a výraznější sladkou chutí - staré víno (vinum vetus), nové víno (vinum novum) a sladké víno (vinum dulce). ${ }^{26}$ Mladá vína a mošty (mustum) choval v oblibě rovněž princ Zikmund. ${ }^{27}$ Význam, který byl produkci a konzumaci vína přikládán v uherském prostředí, našel výraz i v existenci (dnes bohužel nedochovaných) „vinných register“ (regestrum vinorum) ${ }^{28}$ vedených kdysi při tamním královském dvoře. Zmínit lze i zvláštní úřad vinného šenka (vinifer) mající na starost zásobování vínem, jejž staročeský Klaretův slovník obdařil půvabným překladem vínše. ${ }^{29}$

Bylo konstatováno, že řeč účetních záznamů je v prrípadě vína konzumovaného na dvorech Jagellonců v Polsku a v Litvě velmi úsporná, pokud jde o vrstevnatost informací. Zpravidla se dozvídáme pouze tolik, že bylo pro potřeby panovníka a jeho dvořanů nakupováno víno. Panovníkem pověřené osoby přitom byly schopny obstarat poptávaný nápoj v akceptovatelné kvalitě v podstatě ve všech významnějších tržních centrech nalézajících se na území Polského království a Litevského velkoknížectví. ${ }^{30}$ Ostatně Bartoloměj Stein ve svém, pravděpodobně kolem roku 1516 sepsaném díle Descriptio totius Silesie et civitatis regie Vratislaviensis podotkl, že i ve větších slezských městech byla pro movitější zájemce běžně k dostání vína ex Hungaria, Austria, Moravia, a dokonce i dražší vína italská a rýnská. ${ }^{31} \mathrm{~S}$ jeho svědectvím korespondují rovněž detaily z knih jagellonských dvorských účtů. Kancelářský personál pověřený evidencí příjmů a výdajů býval totiž sdílnější právě v těch případech, když došlo z př́ikazu pána dvora k akvizici mimořádně luxusních, a tedy i drahých nápojů. Víme tak, že si polský král Jan Albrecht dopřával i mladá vína a vína rýnská. ${ }^{32}$ Litevský velkokníže a pozdější polský král Alexandr platil desítky kop grošů kupcům ve Vilně a Grodně za italská vína (vinum Italicum). ${ }^{33} \mathrm{Na}$ jaře roku 1500 pak odebral od kupce Pavla z Varšavy dokonce aromatický muškát (muscatella). ${ }^{34}$ Furlánské pignolo (pynol) a rivolu (rivolio) si nechal roku 1495 dopravit z Itálie do uherského Pětikostelí i král Vladislav. ${ }^{35}$ A dvě bečky rivoly byly z Apeninského poloostrova přivezeny rovněž pro potřeby vrchního hejtmana Slezska a Lužic, hlohovského a opavského knížete Zikmunda Jagellonského. ${ }^{36}$

26 NÓGRÁDY, Arpád: Kanizsai László számadáskönyve. Budapest 2011, s. 13, 27-33, 84, 88-89, resp. passim.

27 KOZÁK, P.: Účty dvora, s. 231, 233.

28 FRAKNÓI, V.: II. Lajos király számadási könyve, s. 60.

29 Tamtéž, s. 67; staročeský překlad viz Elektronický slovník staré češtiny. Praha, oddělení vývoje jazyka Ústavu pro jazyk český AV ČR, v. v. i., 2006-, přistupné online: http://vokabular.ujc.cas.cz (verze dat 1. 1. 17, citován stav ze dne 30.4.2021).

30 AGAD, ASK-RK, sign. 20, fol. 2v, 8v, 10r, 10v, 73v, 77r; AGAD, ASK-RK, sign. 22, fol. 1r, 3v, 4v, 5r, 5v, 10r, 13v, 15v, 16r, 22r, 24r, 27r, 30r, 32r, 37v, 41r, 61v, 71r, 77r, 80v, 82r; AGAD, ASK-RK, sign. 31, fol. 6v, 60r, 68v, 69v, 72v, 82r; AGAD, ASK-RK, sign. 34, fol. 59r, 67v, 74v, 88r; ANTANAVIČIUS, D. - PETRAUSKAS, R. : Lietuvos didžiojo kunigaikščio Aleksandro Jogailaičio dvaro sąskaitų knygos, s. 10, 30, 40, 58, 60, 68, 74, 124, 268, 276, 316.

31 MARKGRAF, Herman: Descriptio totius Silesie et civitatis regie Vratislaviensis per M. Bartholomeum Stenum. Barthel Steins Beschreibung von Schlesien und seiner Hauptstadt Breslau. Scriptores rerum Silesiacarum, XVII. Breslau 1902, s. 8.

32 NALEWAJEK, Agnieszka: Na królewskim dworze Jana Olbrachta. Roczniki Humanistyczne 59, 2011, č. 2, s. 68.

33 ANTANAVIČIUS, D. - PETRAUSKAS, R. : Lietuvos didžiojo kunigaikščio Aleksandro Jogailaičio dvaro sąskaitų knygos, s. 30, 60, 68.

34 Tamtéž, s. 68.

35 KOZÁK, P.: Účty budínského dvora, s. 112.

36 TÝŽ: Účty dvora, s. 155, 299, 535. 
Všechny jagellonské dvory pak spojovala slabost pro dobově oblíbený malvaz (malmaticum, malvaticum) - hutné, původem řecké bílé víno, které Urszula Borkowska identifikovala jako synonymum pro silné muškátové víno (infude in ea Muscatellam vel Malmaticum vinum) ${ }^{37}$ Malvaz se počítal mezi tzv. sladká pití a jeho konzumace bývala považována za projev luxusu vyhrazený vyšším a movitějším vrstvám společnosti. Jednalo se bezvýhradně o import, což se projevovalo i v ceně tohoto produktu - ve slezské Vratislavi se tak na počátku 16. století platilo za hrnec malvazu čtrnáct grošů, zatímco cena obyčejného vína o stejném objemu se pohybovala kolem pět a půl groše. ${ }^{38}$ Malvaz nechával nakupovat polský král Jan Albrecht. ${ }^{39}$ Jeho bratr a po roce 1501 nástupce na krakovském trůně, litevský velkokníže Alexandr, platil za soudek malvazu obvykle sedm zlatých - cena zůstávala prakticky shodná, at již se jednalo o trhy v Piotrkowie ležícím v centrální části Polska (v historické zemi sieradzké) nebo v pobaltské Toruni. ${ }^{40} \mathrm{~V}$ Litvě (v Grodně a Vilně) se cena malvazu pohybovala kolem jedné a půl kopy grošů za soudek, což bylo přibližně stejně, není ovšem jisté, zda byl objem „polského“ a „litevského“ soudku (užíváno bylo v obou př́ípadech účetními písaři latinského termínu barilla) plně kompatibilní. ${ }^{41}$ Pravidelně nechávali dovážet ke svým dvorům malvaz princ Zikmund ${ }^{42}$ i jeho královský bratr Vladislav, ${ }^{43}$ stejně jako později Ludvík Jagellonský. ${ }^{44}$ Bez sladkého malvazu se Vladislav nehodlal obejít ani při svých loveckých výpravách do okolí Visegrádu, Taty a Komárna. ${ }^{45}$ A nápoj, jehož název se odvozoval od peloponéského města Malvasia (dnes Monemvasia), nesměl přirozeně chybět ani na jaře roku 1494 při jagellonském rodinném kongresu v Levoči. Na setkání brali osobní účast vedle krále Vladislava jeho mladší bratři polský král Jan Albrecht, kardinál a hnězdenský arcibiskup Fridrich Jagellonský a princ Zikmund, dorazil i jejich švagr markrabě Fridrich V. Braniborsko-ansbašský, manžel Žofie Jagellonské. Chyběl jen litevský velkokníže Alexandr. ${ }^{46} \mathrm{Na}$ panovníkův příkaz a pod dohledem královského šafáře Osvalda Korlátköviho převáželi formani z Budína do Levoče nejen sudy s vínem, počítaje v to i víno sremské, ale právě také malvaz, a to ve značném množství. Z účetní evidence vyplývá, že se jednalo o desítky, ba stovky mázů (pint) malvazu. ${ }^{47} \mathrm{~V}$ časech krále Ludvíka bylo pro běžné zaopatření panovnické tabule

37 BORKOWSKA, Urszula: Przepisy kulinarne Jagiellonek. In: BARTOSZEWICZ, Agnieszka - FAŁKOWSKI, Wojciech - MANIKOWSKA, Halina (eds.): Aetas media, aetas moderna: Studia ofiarowane profesorowi Henrykowi Samsonowiczowi w siedemdziesiata rocznicę urodzin. Warszawa 2000, s. 638, 641.

38 WÓŁKIEWICZ, Ewa: Kuchnia plebana: zwyczajna i nadzwyczajna konsumpcja na parafii św. Jakuba w Nysie (1505-1508). Przegląd Historyczny 102, 2011, č. 4, s. 629.

39 AGAD, ASK-RK, sign. 20, fol. 8v, 9r, 74v.

40 Tamtéž, sign. 31, fol. 62r, 62v, 73v.

${ }^{41}$ ANTANAVIČIUS, D. - PETRAUSKAS, R. : Lietuvos didžiojo kunigaikščio Aleksandro Jogailaičio dvaro sąskaitų knygos, s. 28, 30, 40, 54, 60, 68.

42 KOZÁK, P.: Účty dvora, s. 21, 76, 155, 158, 173-174, 176-177, 196, 206, 234, 258, 298-299, 326, 328-329, 397, 415, 419, 423, 425, 427, 429, 451, 458, 470, 492, 550, 554, 556, 578-580, 642.

43 TÝŽ: Účty budínského dvora, s. 112, 159, 163-164, 195-196, 200, 207, 275.

44 FRAKNÓI, V.: II. Lajos király számadási könyve, s. 67, 69, 72, 76, 92-93, 96, 102-103, 113, 118, 128, 136, $137,145,152,158,166,171,176,184,190,197,207,217,226$.

45 KOZÁK, P.: Účty budínského dvora, s. 207.

${ }_{46}$ BACZKOWSKI, Krzysztof: Państwa jagiellońskie u schyłku średniowiecza. In: SAMSONOWICZ, Henryk (ed.): Schytek średniowiecznej Europy. Warszawa 2003, s. 212 a především FINKEL, Ludwik: Zjazd Jagiellonów w Lewoczy r. 1494. Lwów 1914; DIVÉKY, Adorján: Az 1494. évi lö́csei fejedelmi kongresszus. Lőcse 1913.

47 KOZÁK, P.: Účty budínského dvora, s. 159, 164. 
nakupováno (vedle obyčejného vína a piva) zpravidla sedm mázů, tj. přibližně dvanáct litrů, malvazu na týden. ${ }^{48}$

\section{Pivo}

Pivo, tedy kvašený alkoholický mok vyráběný z obilného sladu, vody a chmele, lze přinejmenším pro oblast širší střední Evropy označit za mimořádně rozšířený nápoj, jehož konzumaci nebyly ve středověku a raném novověku kladeny doslova žádné sociální, genderové ani věkové hranice. Tato skutečnost našla výraz např. ve staročeském rčení sahaje vína, rozléš pivo (pro nejisté ztratíš to, co máš).$^{49}$ Pivo se pak rozlišovalo zejména podle použitého sladu a jeho množství, hovořilo se tak o pivu bílém (pšeničném) a o pivu starém (ječném), žitné slady se používaly jen výjimečně, jejich výskyt indikoval spíše období nedostatku, kdy sloužily jako nouzová náhražka ušlechtilejších sladů pšeničných či ječných. Bílé pivo se obvykle vařilo jako pivo mladé, lehké. Ječný slad byl naproti tomu vyhrazen technologicky náročnější výrobě silnějších, uleželejších a nezřídka prochmelenějších starých piv. Nejsilnějším pivem býval tzv. březňák či marcovní pivo vařené v březnu a uleželé několik týdnů. Dle množství sladu se obecně vařila piva lehká, prostřední, silná až velmi silná. Slabá (lehká) piva zvaná též tenká či řídká, resp. typicky málo kvalitní druhé odvary ze sladu - v českém prostředí se pro ně vžilo přiléhavé označení patoky plnila také úlohu výživné polévky, zejména u osob sociálně níže postavených. Pivo totiž po velmi dlouhý čas nebylo vnímáno jen jako nápoj, ale obecněji jako vydatná, energeticky hodnotná a zdravá potravina. ${ }^{50}$

Podobně jako tomu bylo u vína, také v př́ípadě piva je řeč dochovaných účetních pramenů spojených s provozem dvorů jagellonských monarchů poměrně skoupá na informace, které by vypovídaly o jeho druhu, kvalitě či jakýchkoli jiných vlastnostech. Obvykle se tak v analyzovaných registrech výdajů objevuje povšechný termín pivo (cervisia, cerevisia), byt' lze mít za nepochybné, že mok uvařený v Čechách se chutově i vzhledem lišil od produkce měštanských pivovarů z východních výsep katolické Evropy. Relativně nejsdílnější byl písař, jenž vedl na přelomu 15. a 16. století účty u dvora prince Zikmunda Jagellonského. ${ }^{51}$ Pokud šlo o drahé pivní speciality či importy piv zvučných jmen, neváhal totiž - obdobně jako v případě vzácných vín - tuto skutečnost do svých register zaznamenat. Víme proto, že si za pobytů ve Slezsku princ Zikmund a jeho dvořané nejednou dopřáli doušek proslulého svídnického piva (cervisia Schwidniciensis, cervisia Schwidwiciensis), ${ }^{52}$ které platilo za jedno z vủbec nejchutnějších a současně nejdražších. ${ }^{53}$ Během

\footnotetext{
$48 \quad$ Srov. odkaz na spotřebu malvazu u dvora krále Ludvíka výše.

49 Viz Vokabulár webový : webové hnízdo pramenů k poznání historické češtiny [online]. Praha: Ústav pro jazyk český AV ČR, v. v. i., oddělení vývoje jazyka. (C) 2006-2020. Verze dat 1.1.15 [cit. 20.6. 2020]. Dostupné z: https:// vokabular.ujc.cas.cz (původní digitalizovaný zdroj: BĚLIČ, Jaromír - KAMIŠ, Adolf - KUČERA, Karel: Malý staročeský slovník. Praha 1979).

50 Srov. alespoň BERANOVÁ, Magdalena: Jídlo a pití v pravěku a ve středověku. Praha 2012, s. 149-155; popularizačně STANĚK, Josef: Blahoslavený sládek: Kapitoly z dějin piva. Praha - Litomyšl 1998, passim.

51 Údaje o nákupu piva pro potřeby dvora prince Zikmunda viz KOZÁK, P.: Účty dvora, s. 20, 22-24, 47, 97, 128, 130-133, 142, 159, 173, 175-177, 180-181, 191-193, 195, 255, 267, 297, 299, 302, 320, 324, 327, 329331, 333, 368-370, 372, 402, 408, 415, 420, 422-423, 430, 432, 450, 473, 484, 491-492, 505, 513, 515, 534, $540,553,556,574,577,580,587,604,609,616,622-623,631$.

52 Tamtéž, s. 297, 300, 471.

53 Viz např. KORTA, Wacław (ed.): Świdnica : Zarys monografii miasta. Wrocław - Świdnica 1995, s. 124-125.
} 
zastávky ve Slezské Středě v srpnu roku 1503 musel knížecí šafář dokonce narychlo odjet pryč z města, aby splnil přání svého pána a zajistil, snad na trhu v nedaleké Vratislavi, dostatek svídnického piva. ${ }^{54} \mathrm{~V}$ čase pobytů v Krakově putovala ke stolu knížete nejen piva místní produkce, ale často také pěnivý mok vyrobený v jeden den cesty vzdáleném městě Proszowice (cervisia prosewiana, proscheuiana, proscheviana), ${ }^{55}$ které patřilo k majetkové doméně polských králů. ${ }^{56}$ Cestu si však na knížecí stůl našlo rovněž pivo vyrobené v Piotrkowě (cervisia Pyotrkoviensis). ${ }^{57}$ Za pobytů ve slezské Vratislavi nakupoval knížecí šafář pro mensa domini principis vcelku pravidelně světlé, nejspíše z pšeničného sladu vařené pivo (cervisia alba). ${ }^{58}$ Totožně nazvaný nápoj ochutnal princ Zikmund rovněž v dolnoslezském Klučborku ${ }^{59}$ a především ve své Opavě, ${ }^{60}$ kde navíc počátkem roku 1505 v průběhu zasedání sněmu slezských knížat a stavů zakoupil knížecí šafář sedm věrtelů místního proslulého březňáku (cervisia nigra), ${ }^{61}$ silného tmavého piva vyráběného z ječného sladu, které ve druhé půli 16. století neváhal osobní lékař císaře Rudolfa II. Tadeáš Hájek z Hájku doporučovat coby osvědčenou medicínu. ${ }^{62}$ Věrtel březňáku vyšel knížecí pokladnu na jeden zlatý a šest grošů, zatímco za stejnou míru „běžného“, ovšem vyšším nárokům knížecí tabule odpovídajícího piva platili tehdy služebníci Zikmunda Jagellonského 27 bílých grošů. ${ }^{63}$

Samožrejmě, pěnivý nápoj, který Zikmundův šafář kupoval ad mensam domini principis a jenž byl tedy výslovně určen k rozlévání u knížecí tabule, patřil nepochybně k tomu nejlepšímu, co mohla místní produkce nebo trhy nabídnout. Naproti tomu čeládka se jistě musela spokojit s horšími pivy. Obdobně fakt, že úředníci litevského velkoknížete Alexandra propláceli roku 1500 v Połocku (dnes Polack / Полацк v Bělorusku) nákup piva pro potřeby knížecích maštaléřu a vozků ve výši několika kop grošů, vypovídá podle všeho především o početnosti společnosti, která se pohybovala v blízkosti knížecích stájí. Pivo, jež bylo v téže době určeno přímo velkoknížeti (pro cervisia serenissimo magno duci) a za něž vydala litevská pokladna 24, resp. záhy 28 grošů, muselo mít zcela jinou kvalitativní úroveň. ${ }^{64}$

Pivo náleželo (vedle oblíbeného „aristokratičtějšího“ vína) s železnou pravidelností mezi akvizice směřující k vyživení dvora polského krále Jana Albrechta. Ačkoli jsou vjeho př́padě účetní zápisy mimořádně stručné až kusé, i zde např. zmínky o tom, že pivo bylo čas od času nakupováno spolu s ovsem nebo hrachem, napovídají, že takové pití nejspíše

\footnotetext{
$\overline{54}$ KOZÁK, P.: Účty dvora, s. 297.

55 Tamtéž, s. 172, 174-177, 179, 188, 382, 402, 407. K určení piva srov. účty dvora tehdy již polského krále a litevského velkoknížete Zikmunda I., které vydali WAJS, Anna - WAJS, Hubert: Rachunki podskarbiego Andrzeja Kościeleckiego z lat 1510-1511. Kraków 1997, s. 27-29, 61.

56 KIRYK, Feliks (ed.): Proszowice: Zarys dziejów do 1939 roku. Kraków 2000.

57 KOZÁK, P.: Účty dvora, s. 157. K tamní pivovarské produkci srov. nejnověji MAJEWSKI, Marcin Łukasz: Piwowarstwo miejskie w Piotrkowie w XVI-XVIII wieku. Warszawa 2019.

58 KOZÁK, P.: Účty dvora, s. 328, 330-331, 370, 492.

59 Tamtéž, s. 192.

60 Tamtéž, s. 430 .

61 Tamtéž.

62 Srov. MÜLLER, Karel-ŽÁČEK, Rudolf a kol.: Opava. Praha 2006, s. 142.

63 KOZÁK, P.: Účty dvora, s. 430.

64 ANTANAVIČIUS, D. - PETRAUSKAS, R. : Lietuvos didžiojo kunigaikščio Aleksandro Jogailaičio dvaro sąskaitų knygos, s. 242, 252.
} 
končilo na stolech níže postaveného služebného personálu. Obecněji je možno doložit, že pověření úředníci nakupovali pivo na trzích v Krakově, Poznani, Radomi, Sandoměři či ve městě Nowy Sącz. Lze přitom předpokládat, že se jednalo o místní produkci. Ostatně při panovníkově pobytu v Brestu Kujavském (Brześć Kujawski) se v účtech výslovně hovoří o tom, že vozkové pěnivý mok pro svého pána přivezli právě z onoho místa. Výdaje za pivo ze strany královské pokladny rychle narůstaly např. v době zasedání sněmů, jako tomu bylo v Radomi roku 1494, kdy platby v groších ustoupily platbám ve zlatých. ${ }^{65}$

Pivo bývalo obvykle lacinější než víno srovnatelné kvalitativní úrovně, zejména to platilo v zemích, kde byla domácí vinařská produkce zastoupena slabě či vủbec. Také sociální hodnota piva byla, jak již bylo řečeno, nižší než u vína. Vínu (snad) dávali přednost Jan Albrecht i jeho bratr Alexandr. ${ }^{66}$ Oba však prokazatelně konzumovali rovněž pivo. Alexandr Jagellonský nechával pro potřeby svého velkoknížecího, resp. královského dvora nakupovat pěnivý mok uvařený v polském Piotrkowě stejně jako v četných větších i menších lokalitách nalézajících se v hranicích Litevského velkoknížectví, jako bylo Vilno, Minsk, Połock, Borysów (dnes Barysau / Барысаy̆ v Bělorusku), Obolce (dnes Abol'cy / Абольцы v Bělorusku), Mieżawa (dnes Mežava / Межава v Bělorusku), Smolany (dnes Smaljany / Смалья́ны v Bělorusku), Łukoml (dnes Lukoml'/ Лукомль v Bělorusku), Turzec (dnes Turec / Турэц v Bělorusku) a Orany (dnes Varẻna na Litvě). ${ }^{67}$ Také pivem se hostilo - roku 1505 neváhal Alexandr během jednání se zástupci Tatarů v Lublinu vyplatit celé tři hřivny grošů za nákup piva uvařeného v padesát kilometrů vzdáleném městě Kock (pro cervisia Cocensi) ${ }^{68}$

Pavel Trnka na základě pečlivé analýzy zápisů v tzv. verkových registrech vedených při úřadu kutnohorské mincovny soudil, že nejoblíbenějším nápojem u dvora krále Vladislava bylo víno. Pivo se mělo spotřebovávat v menším množství, doložil přitom nákupy sudů piva hradeckého a kouřimského, jejichž dodávky měl mít na starosti královský šenk. ${ }^{69}$ Dochovaný registr prŕijmů a výdajů krále Vladislava za léta 1494-1495, sestavený pro potřeby uherského královského pokladníka Zikmunda Ernuszta, Trnkovu domněnku potvrzuje. Vedle evidovaných plateb za víno a malvaz totiž neobsahuje ani jeden jediný zápis o nákupu piva. Jak vidno, přesídlení Vladislava a jeho dvora do Uher proslulých produkcí kvalitních vín (budínské trhy navíc nepostrádaly účinné napojení na balkánskou a zejména italskou vinařskou produkci) posílilo chutové preference pána dvora a spotřebu piva zcela upozadilo. Ostatně rovněž účty prince Zikmunda Jagellonského ukazují, že zvýšená konzumace piva nebo vína de facto kopírovala itinerář jagellonského kralevice pobyty v Uhrách se vždy nesly ve znamení růstu spotřeby vína, naopak pro období strávené ve Slezsku a v Polsku převažují záznamy o nákupech nejrůznějších druhů piv. Slabost pro uherská vína a ruku v ruce s tím i ochota investovat nemalé sumy peněz do jejich importu u něj nicméně rovněž přetrvávala. Naproti tomu uherský a český král Ludvík si potrpěl jak na víno (a malvaz), tak na pivo - soudek piva v ceně tři až čtyř zlatých býval

\footnotetext{
AGAD, ASK-RK, sign. 20, fol. 63r, 64v; Tamtéž, sign. 22, fol. 12v, 15v, 22v, 25r, 36r (celkem 6x), 37r, 38v; Tamtéž, sign. 24, fol. 78v.

66 V prŕpadě Jana Albrechta tak soudila NALEWAJEK, A.: Na królewskim dworze, s. 67.

67 AGAD, ASK-RK, sign. 31, fol. 60v; Tamtéž, sign. 34, fol. 88r; ANTANAVIČIUS, D. - PETRAUSKAS, R.: Lietuvos didžiojo kunigaikščio Aleksandro Jogailaičio dvaro sąskaitų knygos, s. 80, 206, 218, 222, 228, 234, 236, 238, 240, 242, 244, 248, 252, 256, 290, 306, 320.

68 AGAD, ASK-RK, sign. 34, fol. 88r.

69 TRNKA, P.: Výdaje dvora, s. 282.
} 
ad mensam Regie Maiestatis či ještě výstižněji pro ore Regie Maiestatis, a tedy pro přímou osobní spotřebu panovníka nakupován zcela pravidelně. ${ }^{70}$

\section{Destiláty a medovina}

Třetí skupinu alkoholických nápojů, které byly dle dochovaných účetních knih konzumovány na dvorech králů a knížat $\mathrm{z}$ dynastie Jagellonců, tvoří destiláty a medovina. V tomto př́padě se ovšem nečetné pramenné zmínky omezují - až na jednu jedinou výjimku, u níž se ještě zastavíme - na oblast Polska a Litvy. Záznamy o spotřebě alkoholu vyráběného destilací a medoviny, tedy nápoje vznikajícího fermentací včelího medu, pocházejí z evidence příjmů a výdajů dvora polského krále a litevského velkoknížete Alexandra. Převážně se přitom jednalo o alkohol vyráběný pálením méně hodnotných či znehodnocených vín. Zřetelně to vyplývá $\mathrm{z}$ řeči účetních záznamů, $\mathrm{v}$ nichž se hovoří o výdajích pro vino palone, resp. pro vino sublimato. ${ }^{71}$ Jen $\mathrm{v}$ jednom případě lze usuzovat na destilát $\mathrm{z}$ obilí odpovídající snad dnešní vodce, nebot účetní písař považoval za vhodnější užít k jeho charakteristice slova liquor.$^{72}$ Destiláty byly u dvora Alexandra Jagellonského prokazatelně používány jak k účelům lékařským (ad medicinam regie maiestatis), tak, byt' výjimečně, ke konzumaci u panovníkovy tabule. Roku 1505 cestou do malopolského Lublinu totiž bylo vinum sublimatum v hodnotě 14 grošů servírováno Tatarům, kteří doprovázeli v exilu pobývajícího chána zaniklé Velké (Zavolžské) Hordy Šajch Achmata při společné večeři s polsko-litevským panovníkem. ${ }^{73}$ Pálenku z vína si navíc dopřál i kníže Zikmund na podzim roku 1502 při jednom ze svých uherských pobytů, konkrétně během zastávky v Ostřihomi po překonání Dunaje, kdy písař stojící v jeho službách zaevidoval výdaj osm uherských denárů pro vino palone et pro vitro domino principi. ${ }^{74}$

Nápoje spadající do kategorie tzv. tvrdého alkoholu byly, pokud šlo o vyšší vrstvy společnosti, na přelomu 15. a 16. století vůbec doménou drsnějších, kurtoazních mravů křestanského světa neznalých válečníků z řad kočovných turkických národů shrnovaných v dobových písemných pramenech obvykle pod pojmem Tataři. Přinejmenším tedy hovoříme-li o nápojové kultuře spojované s prostředním panovnických dvorů. Vedle pálenky z vína tak úředníci polského krále zásobovali reprezentanty společenské elity bývalé Veké Hordy medovinou. Cestou do Lublinu byla pro ně roku 1505 na př́kaz Alexandra Jagellonského zakoupena objemná bečka (tunna) medoviny v ceně tři zlatých a devíti grošů. A medovinu popíjel s Alexandrem při snídani v Proszowicích rovněž

\footnotetext{
70 FRAKNÓI, V.: II. Lajos király számadási könyve, s. 68, 77, 91, 106, 122, 136, 152, 173, 179-189, 203, 217, 226; ENGEL, J. Ch.: Fragmentum libri rationarii, s. 196. Rytmus všedního i svátečního dne u dvora krále Ludvíka představila DVOŘÁKOVÁ, Daniela: Zábava a slávnosti na uhorskom král'ovskom dvore (na príklade dvora uhorského král'a Ludovíta II. Jagelovského). In: Dvory a rezidence ve středověku III : Všední a sváteční život na středověkých dvorech. Mediaevalia Historica Bohemica 12, 2009. Supplementum 3, s. 179-191.

71 AGAD, ASK-RK, sign. 34, fol. 77v, 79r, 87v.

72 ANTANAVIČIUS, D. - PETRAUSKAS, R.: Lietuvos didžiojo kunigaikščio Aleksandro Jogailaičio dvaro sąskaitų knygos, s. 320.

73 Item pro vino sublimato Tataris, dum in prandio fuerunt cum cezare zawolhensi, gr. XIIII. Viz AGAD, ASK-RK, sign. 34, fol. 87v. K pádu Velké Hordy a osudům jejího posledního chána srov. nejnověji MIKA, Norbert: Problematyka tatarska w polityce europejskiej od połowy XV do początku XVI wieku. Kraków - Warszawa 2020, s. 63-65, 360-368.

74 KOZÁK, P.: Účty dvora, s. 246.
} 
zmiňovaný chán Šajch Achmat. ${ }^{75} \mathrm{Na}$ „východě“ zkrátka panovaly jiné poměry. Nepřekvapí proto, že si na sladce omamné medovině pochutnával roku 1471 také posel moskevského velkoknížete Ivana III. ${ }^{76}$

\section{Závěr}

Představená sonda do nabídky nápojů, s nimiž se bylo možno setkat na dvorech jagellonských panovníků z doby konce středověku, je nutně nedokonalá, předběžné závěry nicméně formulovat lze. Každodenní i sváteční pití se neslo ve znamení pravidelné konzumace alkoholických nápojů, jak tomu bylo dobově zvykem. ${ }^{77}$ Voda bezpochyby měla u dvorů monarchů $\mathrm{z}$ dynastie Jagellonců své místo, nebylo ji však zpravidla nutno nakupovat. ${ }^{78}$ Otisk její spotřeby v dochovaném účetnictví je tak spíše dílem náhody a pojí se obvykle se zmínkami o návštěvě lázní. Jestliže tak Vladislav Jagiełło a jeho syn Kazimír IV. odmítali omamné nápoje, jak o tom alespoň ve svých kronikářských dílech hovořili Jan Długosz a Matěj Stryjkowski, ${ }^{79}$ byl vztah dalších generací Jagellonců k alkoholu o poznání kladnější. Pilo se především víno a pivo, lihoviny a medovina se na stůl vznešené společnosti přelomu 15. a 16. století dostávaly jen zřídka a náležely spíše světu neurozených, méně kultivovaných lidí. Dvorská elita si potrpěla na luxusní nápoje - kvalitní, obtížněji dostupná, a tedy i drahá vína, resp. na regionálně proslulé druhy piv. Platilo přitom, že víno bylo „vznešenějším“ nápojem než pivo a jeho zvýšená konzumace vhodným způsobem dotvářela představu o sociální výlučnosti panovníka a jeho nejbližšího okolí. Jakkoli se tak ve spotřebě prokazatelně odrážely rovněž chutové preference konzumentů, nelze podceňovat ani sílu společenského tlaku se snahou naplnit očekávatelné vzorce chování. Řeč účetních záznamů bývá často strohá, zápisy se zpravidla omezují na konstatování výdajů za víno či pivo bez kvalitativních či jiných charakteristik. Sdílnější bývali účetní písaři jen tehdy, došlo-li na nákup skutečně exkluzivních komodit (sremská a italská či řecká vína). Geografický původ nápojů lze proto povětšinou pouze odhadovat, zvláště když panovník měl možnost vytěžit možnosti, které poskytovala větší tržní centra. Lze shrnout, že výsledky průzkumu dochovaných knih účtů vedených při dvorech potomků krále Kazimíra IV. odpovídají v hlavních rysech obecnější představě o dobové skladbě aristokratického jídelníčku. Analytická sonda nicméně nabídla řadu konkrétních detailů, a snad tak posunula téma $\mathrm{z}$ oblasti hypotéz a analogií odjinud směrem k jistěji podloženým soudům.

\footnotetext{
75 AGAD, ASK-RK, sign. 34, fol. 69r, 87r, 87v, 88r.

76 PERZANOWSKI, Z. - STRZELECKA, A.: Rachunki wyprawy, s. 88.

77 Srov. HRDLIČKA, Josef: Hodovní stůl a dvorská společnost : Strava na raně novověkých aristokratických dvorech v českých zemích (1550-1650). České Budějovice 2000, s. 213-218. Uherskou a polskou perspektivu nabídli DVOŘÁKOVÁ, Daniela: Rytier a jeho král. Stibor zo Stiboríc a Žigmund Luxemburský : Sonda do života stredovekého uhorského šlachtica s osobitným zretelom na územie Slovenska. Budmerice - Bratislava 2010, s. 205-207; BESALA, Jerzy: Alkoholowe dzieje Polski : Czasy Piastów i Rzeczypospolitej szlacheckiej. Poznań 2015.

78 Podrobněji KOZÁK, Petr: Meals and beverages on Prince Sigismund's dining table: Some remarks on the possibilities of knowing the diet of the Jagiellonian rulers at the turn of the 15th and 16th centuries. Perspektywy kultury: Czasopismo naukowe Instytutu Kulturoznawstwa Akademii Ignatium w Krakowie 15, 2016, č. 2 , s. 97.

Např. NALEWAJEK, A.: Na królewskim dworze, s. 67.
} 


\section{Bibliografie}

\section{Archivní prameny}

Archiwum Główne Akt Dawnych, Archiwum Skarbu Koronnego z lat 1388-1826 (Nr. Zespołu: 7), Oddział 1 Rachunki Królewskie, 1388-1781, sign. 20, 22, 24, 26, 28, 30-32, 34.

\section{Tištěné prameny}

ANTANAVIČIUS, Darius - PETRAUSKAS, Rimvydas: Lietuvos didžiojo kunigaikščio Aleksandro Jogailaičio dvaro sąskaitų knygos (1494-1504). Vilnius 2007.

E. KOVÁCS, Péter: Estei Hippolit püspök Egri számadáskönyvei 1500-1508. Eger 1992.

ENGEL, Johann Christian: Fragmentum libri rationarii super erogationibus aulae Regis Hungariae Ludovici II. de anno 1526. In: TÝŽ: Monumenta Ungrica. Viennae 1809, s. 185-236.

FRAKNÓI, Vilmos: II. Lajos király számadási könyve. 1525. január 12-július 16., In: Magyar történelmi tár XXII. Budapest 1877, s. 45-236.

KOZÁK, Petr - RÁBAI, Krisztina: Mezi periferií a centrem jagellonského světa: Registrum dvoranů knížete a krále Zikmunda I. Jagellonského z let 1493-1510 / Between the Periphery and the Centre of the Jagiellonian World: The Register of Courtiers of Prince and King Sigismund I Jagiellon from 1493-1510. Opava 2015.

KOZÁK, Petr: Účty budínského dvora krále Vladislava II. Jagellonského (1494-1495). Praha 2019.

KOZÁK, Petr: Účty dvora prince Zikmunda Jagellonského, vévody hlohovského a opavského, nejvyššího hejtmana Slezska a Lužic, z let (1493) 1500-1507: Kritická edice pramene / Rationes curiae Sigismundi Iagellonici, ducis Glogoviensis et Opaviensis, Silesiae et Lusatiarum summi capitanei, de annis (1493) 1500-1507:Editio critica. Praha 2014.

MARKGRAF, Herman: Descriptio totius Silesie et civitatis regie Vratislaviensis per M. Bartholomeum Stenum. Barthel Steins Beschreibung von Schlesien und seiner Hauptstadt Breslau. Scriptores rerum Silesiacarum, XVII. Breslau 1902.

NEUMANN, Tibor: Registrum proventuum regni Hungariae : A Magyar Királyság kincstartójának szá-madáskönyve (1494-1495). Budapest 2019.

NÓGRÁDY, Arpád: Kanizsai László számadáskönyve. Budapest 2011.

PERZANOWSKI, Zbigniew - STRZELECKA, Anna: Część I: Rachunki wyprawy Władysława Jagiellończyka do Czech w latach 1471-1472. In: GAWĘDA, Stanisław - PERZANOWSKI, Zbigniew - STRZELECKA, Anna: Rachunki królewskie z lat 1471-1472 i 1476-1478. Wrocław - Kraków 1960, s. 1-101.

WAJS, Anna - WAJS, Hubert: Rachunki podskarbiego Andrzeja Kościeleckiego z lat 1510-1511. Kraków 1997.

\section{Internetové a jiné zdroje}

CEISEL, Christina: Food Studies, In: OxfordResearch Encyclopedia of Communication. Oxford 2017. Online, cit. 1. 9. 2021 dostupné na https://doi.org/10.1093/acrefore/9780190228613.013.580, resp. https://oxfordre. com/communication/view/10.1093/acrefore/9780190228613.001.0001/acrefore-9780190228613-e-580.

Elektronický slovník staré češtiny. Praha, oddělení vývoje jazyka Ústavu pro jazyk český AV ČR, v. v. i., 2006, př́stupné online: http://vokabular.ujc.cas.cz (verze dat 1.1.17, citován stav ze dne 30.4. 2021).

Vokabulář webový: webové hnízdo pramenů k poznání historické češtiny [online]. Praha: Ústav pro jazyk český AV ČR, v. v. i., oddělení vývoje jazyka. (C) 2006-2020. Verze dat 1.1.15 [cit. 20. 6. 2020]. Dostupné z: https:// vokabular.ujc.cas.cz.

\section{Literatura}

BACZKOWSKI, Krzysztof: Państwa jagiellońskie u schyłku średniowiecza. In: SAMSONOWICZ, Henryk (ed.): Schytek średniowiecznej Europy. Warszawa 2003, s. 205-223.

BERANOVÁ, Magdalena: Jídlo a pití v pravěku a ve středověku. Praha 2012.

BESALA, Jerzy: Alkoholowe dzieje Polski : Czasy Piastów i Rzeczypospolitej szlacheckiej. Poznań 2015.

BOŁDYREW, Aleksander - BOŁDYREW, Aneta: Royal Bills as the Source of the History of Taste and Food in Poland of the Last Jagiellons : Basic Sources and Research Possibilities. Piotrkowskie Zeszyty Historyczne 15, 2014, s. 11-27.

BORKOWSKA, Urszula: Przepisy kulinarne Jagiellonek. In: BARTOSZEWICZ, Agnieszka - FAŁKOWSKI, Wojciech - MANIKOWSKA, Halina (eds.): Aetas media, aetas moderna : Studia ofiarowane profesorowi Henrykowi Samsonowiczowi w siedemdziesiąta rocznicę urodzin. Warszawa 2000, s. 632-642.

BORKOWSKA, Urszula: Rachunki królewskie jako źródło poznania praktyk religijnych Jagiellonów. In: BORKOWSKA, Urszula - KNAPIŃSKI, Riszard - PIŁAT, Zbigniew - WIŚNIOWSKI, Eugeniusz (eds.): Peregrinatio ad veritatem : Studia ofiarowane profesor Aleksandrze Witkowskiej OSU z okazji 40-lecia pracy naukowej. Lublin 2004, s. 47-63. 
C. TÓTH, Norbert: Politikatörténeti források Bátori István első helytartóságához (1522-1523). Budapest 2010. DIVÉKY, Adorján: Az 1494 : évi lócsei fejedelmi kongresszus. Lőcse 1913.

DVOŘÁKOVÁ, Daniela: Rytier a jeho král. Stibor zo Stiboríc a Žigmund Luxemburský: Sonda do života stredovekého uhorského šlachtica s osobitným zretelom na územie Slovenska. Budmerice - Bratislava 2010.

DVOŘÁKOVÁ, Daniela: Zábava a slávnosti na uhorskom královskom dvore (na príklade dvora uhorského krála Ludovíta II. Jagelovského). In: Dvory a rezidence ve středověku III. : Všední a sváteční život na středověkých dvorech. Mediaevalia Historica Bohemica 12, 2009. Supplementum 3, s. 179-191.

FINKEL, Ludwik: Zjazd Jagiellonów w Lewoczy r. 1494. Lwów 1914.

HRDLIČKA, Josef: Hodovní stůl a dvorská společnost : Strava na raně novověkých aristokratických dvorech $v$ českých zemích (1550-1650). České Budějovice 2000.

JANÁK, Dušan a kol.: Jídlo není jenom „něco k jídlu“ : Tradiční stravování a pokrmy jako součást regionální a národní identity ve vědomí a paměti současné společnosti. Opava 2020.

JEDLIČKOVÁ, Blanka - LENDEROVÁ, Milena - KOUBA, Miroslav - ŘíHA, Ivo (eds.): Krajiny prostřených i prázdných stolů I. : Evropská gastronomie v proměnách staletí. Pardubice 2016.

JEDLIČKOVÁ, Blanka - LENDEROVÁ, Milena - KOUBA, Miroslav - ŘíHA, Ivo (eds.): Krajiny prostřených i prázdných stolů II. : Evropská gastronomie v interdisciplinárním př́stupu. Pardubice 2017.

KAMLER, Anna - PIETRZKIEWICZ, Dorota - SEROKA, Katarzyna (eds): Polska i świat przez kuchnię : Studia o dziedzictwie kulinarnym. Warszawa 2018.

KIRYK, Feliks (ed.): Proszowice : Zarys dziejów do 1939 roku. Kraków 2000.

KORBELÁŘOVÁ, Irena - DLUHOŠOVÁ, Radmila - SOBOTKOVÁ, Jitka: Pamět chuti : Receptáře a kuchařské knihy jako specifické prameny pro poznání kulinární kultury a kulinárního dědictví českých zemí. Opava 2020.

KORBELÁŘOVÁ, Irena - ZEZULA, Michal (eds): S knižaty u stolu: Kuchyně a kultura stolování na středověkých vévodských dvorech v Opavě a Ratiboři. Ostrava - Racibórz 2018.

KORBELÁŘ́VÁ, Irena a kol.: Kulinární kultura Slezska a střední Evropy : Východiska, metody, interdisciplinarita. Opava 2015.

KORTA, Wacław (ed.): Świdnica :Zarys monografii miasta.Wrocław - Świdnica 1995.

KOZÁK, Petr: Income and expenditures of the Hungarian Royal Chamber during the first ruling years of King Vladislaus Jagiellon: analysis of an accounting register from the years 1494-1495. In: SLAVÍČKOVÁ, Pavla (ed.): A History of the Credit Market in Central Europe : The Middle Ages and Early Modern Period. London - New York 2020, s. 42-51.

KOZÁK, Petr: Meals and beverages on Prince Sigismund's dining table : Some remarks on the possibilities of knowing the diet of the Jagiellonian rulers at the turn of the 15th and 16th centuries. Perspektywy kultury: Czasopismo naukowe Instytutu Kulturoznawstwa Akademii Ignatium w Krakowie 15, 2016, č. 2, s. 61-107.

LENDEROVÁ, Milena - KOUBA, Miroslav - KOZÁR, Aleš - ŘíHA, Ivo: „Spanilost Vaše cizozemcům se líbí... “ : České kuchařské knihyv 19. století. Červený Kostelec 2017.

MAJEWSKI, Marcin Łukasz: Piwowarstwo miejskie w Piotrkowie w XVI-XVIII wieku. Warszawa 2019.

MIKA, Norbert: Problematyka tatarska w polityce europejskiej od polowy XV do początku XVI wieku. Kraków Warszawa 2020.

MÜLLER, Karel - ŽÁČEK, Rudolf a kol.: Opava. Praha 2006.

NALEWAJEK, Agnieszka: Na królewskim dworze Jana Olbrachta. Roczniki Humanistyczne 59, 2011, č. 2, s. 41-80.

STANĚK, Josef: Blahoslavený sládek : Kapitoly z dějin piva. Praha - Litomyšl 1998.

TRNKA, Pavel: Výdaje dvora Vladislava Jagellonského v letech 1471-1490. In: Dvory a rezidence ve středověku III. : Všední a sváteční život na středověkých dvorech. Mediaevalia Historica Bohemica 12, 2009. Supplementum 3, s. 271-292.

WÓŁKIEWICZ, Ewa: Kuchnia plebana: zwyczajna i nadzwyczajna konsumpcja na parafii św. Jakuba w Nysie (1505-1508). Przeglad Historyczny 102, 2011, č. 4, s. 609-635.

\section{Summary}

\section{Beverages at the Courts of the Kings and Princes of the Jagiellonian Dynasty in the Late $15^{\text {th }}$ and early $16^{\text {th }}$ Century}

The present study is an analytical probe into the field of beverage culture as it was cultivated in the late $15^{\text {th }}$ and early $16^{\text {th }}$ century at the courts of the descendants of the Polish-Lithuanian ruler Casimir IV († 1492) of the Jagiellonian dynasty. The research is based on a comprehensive analysis of rare, preserved account books kept at the courts of the following Jagiellonians: the Czech and Hungarian 
king Vladislaus ( $\dagger 1516)$, his son, the Czech and Hungarian king Louis ( $\dagger 1526)$, and then his brothers, the Polish king John Albert ( $\dagger$ 1501), the grand duke of Lithuania and later also the Polish king Alexander ( $\dagger 1506)$. The set of accounting sources is concluded by the accounting records kept at the court of Prince Sigismund ( $\uparrow 1548$ ), later known as the Polish-Lithuanian ruler Sigismund I the Old. Before taking the thrones in Kraków and Vilna, he moved between the courts of his reigning brothers, became the Duke of Opava and Gtogów and held the office of governor of Silesia and both Lusatias between 1504 and 1506/1507. Focusing on the members of the Jagiellonian dynasty in one or two generations is productive thanks both to the unique source base (court accounts) and to the fact that the Jagiellonians controlled vast areas of Central and Central-Eastern Europe at that time. Countries with different historical (including culinary) traditions, economic opportunities and natural conditions found themselves under the rule of the Jagiellonians. Alcoholic beverages were consumed at the courts of all the dynasty members. Although Władystaw II Jagietlo and his son Casimir IV are said to have rejected intoxicating beverages, the attitude of the following generations of Jagiellonians to alcohol was much more prosaic. People drank mainly wine and beer. Spirits and mead rarely reached the table of the noble society of the late $15^{\text {th }}$ and early $16^{\text {th }}$ century and belonged rather to the world of lowborn or less sophisticated people (typically Tatar warriors and their leaders). The court elite were fond of luxury drinks - high quality, harder to find and therefore expensive kinds of wine or beer. Wine was considered to be a more noble drink than beer, and drinking it added to the idea of social exclusivity of the ruler and his immediate circle. While consumption has been shown to reflect consumers 'taste preferences, the power of social pressure to conform to expected patterns of behaviour cannot be underestimated. The language of accounting records is often terse, with entries generally limited to a statement of expenditure on wine or beer without qualitative or other characteristics. Scribes were more expansive only when it came to the purchase of truly exclusive commodities (Srem and Italian or Greek wines or the popular Malvasia). The geographical origin of beverages could usually only be guessed, especially when the ruler could benefit from more than one trade centre he controlled. In summary, the results of the survey of the surviving account books kept at the courts of King Casimir IV's descendants correspond in broad outlines to a more general idea of the composition of the aristocratic diet at that time. However, the analytical probe offers a number of specific details and moves the topic from the realm of hypotheses and analogies towards more confident conclusions. 